\title{
Supporting Information: Structure, energetics, and spectra for the oxygen vacancy in rutile: prominence of the Ti-Ho-Ti bond
}

William R. Palfey ${ }^{a}$, George R. Rossman ${ }^{a, *}$, William A Goddard III ${ }^{b, *}$

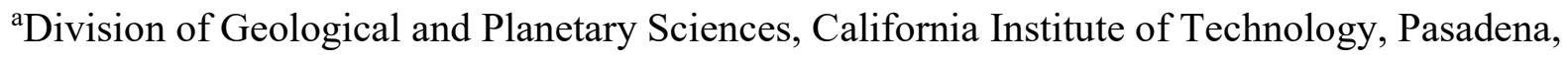
CA, USA

${ }^{\mathrm{b}}$ Materials and Process Simulation Center (MSC), MC 139-74, California Institute of Technology, Pasadena CA, 91125, USA

* To whom correspondence is to be addressed: wag@caltech.edu; grr@caltech.edu ORCID: WAG) 0000-0003-0097-5716; WP, GRR 0000-0002-4571-6884 
TABLE OF CONTENTS

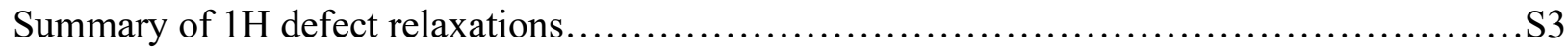

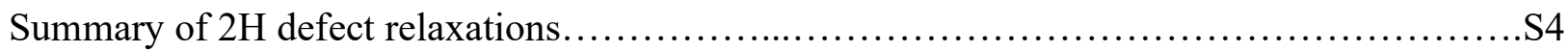

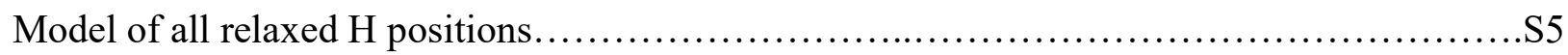

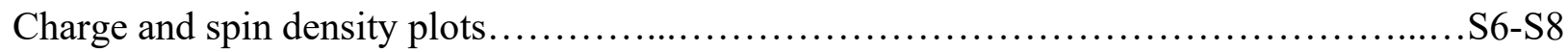

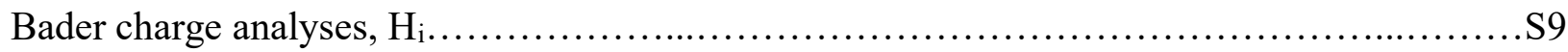

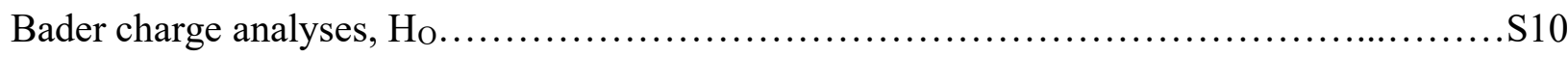

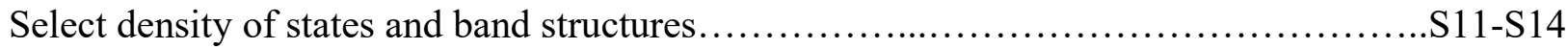

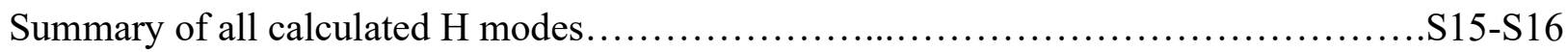

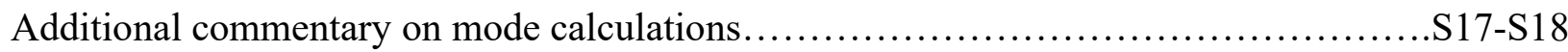

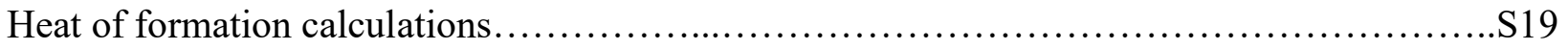

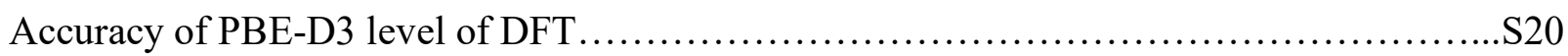


Table S1. The energies, hydrogen bonding distances and hydrogen bond angles for all 21 of the single $\mathrm{H}$ defects. Ending positions of " $\mathrm{H}_{\mathrm{i}}$ " are all $\mathrm{CC}$ oriented.

\begin{tabular}{|c|c|c|c|c|}
\hline Defect site & Final H position & Total energy (eV) & $d(O H \cdots O)(\AA)$ & Ti-O-H angle \\
\hline $\mathrm{H}_{\mathrm{A} 2}$ & $\mathrm{H}_{\mathrm{O}}$ & -432.066 & N/A & N/A \\
\hline $\mathrm{H}_{\mathrm{K} 2}$ & $\mathrm{H}_{\mathrm{i}}$ & -430.647 & 2.95 & 173.0 \\
\hline $\mathrm{H}_{\mathrm{D} 3}$ & $\mathrm{H}_{\mathrm{i}}$ & -430.629 & 2.83 & 174.3 \\
\hline $\mathrm{H}_{\mathrm{M} 2}$ & $\mathrm{H}_{\mathrm{i}}$ & -430.623 & 2.95 & 173.2 \\
\hline $\mathrm{H}_{\mathrm{E} 4}$ & $\mathrm{H}_{\mathrm{i}}$ & -430.577 & 2.91 & 172.7 \\
\hline $\mathrm{H}_{\mathrm{G} 3}$ & $\mathrm{H}_{\mathrm{i}}$ & -430.550 & 2.83 & 172.8 \\
\hline $\mathrm{H}_{\mathrm{J}}$ & $\mathrm{H}_{\mathrm{i}}$ & -430.539 & 2.96 & 172.0 \\
\hline $\mathrm{H}_{\mathrm{H} 4}$ & $\mathrm{H}_{\mathrm{i}}$ & -430.501 & 2.90 & 171.7 \\
\hline $\mathrm{H}_{\mathrm{F} 3}$ & $\mathrm{H}_{\mathrm{i}}$ & -430.489 & 2.97 & 172.4 \\
\hline $\mathrm{H}_{\mathrm{J} 4}$ & $\mathrm{H}_{\mathrm{i}}$ & -430.488 & 3.21 & 168.3 \\
\hline $\mathrm{H}_{\mathrm{B} 2}$ & $\mathrm{H}_{\mathrm{i}}$ & -430.484 & 3.00 & 173.4 \\
\hline $\mathrm{H}_{13}$ & $\mathrm{H}_{\mathrm{i}}$ & -430.478 & 3.01 & 171.4 \\
\hline $\mathrm{H}_{\mathrm{H} 3}$ & $\mathrm{H}_{\mathrm{i}}$ & -430.47 & 3.08 & 171.3 \\
\hline $\mathrm{H}_{\mathrm{F} 4}$ & $\mathrm{H}_{\mathrm{i}}$ & -430.443 & 2.96 & 172.4 \\
\hline $\mathrm{H}_{14}$ & $\mathrm{H}_{\mathrm{i}}$ & -430.44 & 2.95 & 175.7 \\
\hline $\mathrm{H}_{\mathrm{E} 3}$ & $\mathrm{H}_{\mathrm{i}}$ & -430.385 & N/A & N/A \\
\hline $\mathrm{H}_{\mathrm{D} 4}$ & $\mathrm{H}_{\mathrm{i}}$ & -430.374 & 2.88 & 164.4 \\
\hline $\mathrm{H}_{\mathrm{G} 4}$ & $\mathrm{H}_{\mathrm{i}}$ & -430.37 & 2.96 & 170.1 \\
\hline $\mathrm{H}_{\mathrm{C} 2}$ & $\mathrm{H}_{\mathrm{i}}$ & -430.295 & 2.94 & 173.1 \\
\hline $\mathrm{H}_{\mathrm{L} 2}$ & $\mathrm{H}_{\mathrm{i}}$ & -430.238 & 2.96 & 175.2 \\
\hline $\mathrm{H}_{\mathrm{N} 2}$ & $\mathrm{H}_{\mathrm{i}}$ & -430.187 & 2.95 & 172.9 \\
\hline
\end{tabular}


Table S2. The energies, hydrogen bonding distances, hydrogen bond angles and average Ti-H distances for all 21 of the two $\mathrm{H}$ defects. Ending positions of " $\mathrm{H}_{\mathrm{i}}$ " are all $\mathrm{CC}$ oriented.

\begin{tabular}{|c|c|c|c|c|c|c|}
\hline Defect sites & Final H positions & Total energy $(\mathrm{eV})$ & $d(O H \cdots O)(\AA)$ & Avg. Ti-H (Å) & \multicolumn{2}{|r|}{ Ti-O-H angle } \\
\hline $\mathrm{H}_{\mathrm{A} 2}, \mathrm{H}_{\mathrm{M} 2}$ & $\mathrm{H}_{\mathrm{O}}, \mathrm{H}_{\mathrm{i}}$ & -435.093 & 2.94 & 2.04 & & 173.1 \\
\hline $\mathrm{H}_{\mathrm{A} 2}, \mathrm{H}_{\mathrm{E} 4}$ & $\mathrm{H}_{0}, \mathrm{H}_{\mathrm{i}}$ & -435.085 & 2.91 & 2.03 & & 173.1 \\
\hline $\mathrm{H}_{\mathrm{A} 2}, \mathrm{H}_{\mathrm{K} 2}$ & $\mathrm{H}_{0}, \mathrm{H}_{\mathrm{i}}$ & -435.084 & 2.96 & 2.03 & & 173.4 \\
\hline $\mathrm{H}_{\mathrm{A} 2}, \mathrm{H}_{\mathrm{G} 3}$ & $\mathrm{H}_{0}, \mathrm{H}_{\mathrm{i}}$ & -435.074 & 2.83 & 2.04 & & 174.9 \\
\hline $\mathrm{H}_{\mathrm{A} 2}, \mathrm{H}_{\mathrm{D} 3}$ & $\mathrm{H}_{0}, \mathrm{H}_{\mathrm{i}}$ & -435.070 & 2.81 & 2.04 & & 173.6 \\
\hline $\mathrm{H}_{\mathrm{A} 2}, \mathrm{H}_{\mathrm{F} 3}$ & $\mathrm{H}_{\mathrm{O}}, \mathrm{H}_{\mathrm{i}}$ & -435.041 & 2.95 & 2.04 & & 172.8 \\
\hline $\mathrm{H}_{\mathrm{A} 2}, \mathrm{H}_{13}$ & $\mathrm{H}_{0}, \mathrm{H}_{\mathrm{i}}$ & -435.037 & 2.89 & 2.03 & & 173.5 \\
\hline $\mathrm{H}_{\mathrm{A} 2}, \mathrm{H}_{\mathrm{J} 3}$ & $\mathrm{H}_{0}, \mathrm{H}_{\mathrm{i}}$ & -435.023 & 2.92 & 2.04 & & 173.1 \\
\hline $\mathrm{H}_{\mathrm{A} 2}, \mathrm{H}_{\mathrm{H} 4}$ & $\mathrm{H}_{0}, \mathrm{H}_{\mathrm{i}}$ & -435.017 & 2.92 & 2.03 & & 173.4 \\
\hline $\mathrm{H}_{\mathrm{A} 2}, \mathrm{H}_{\mathrm{J} 4}$ & $\mathrm{H}_{\mathrm{O}}, \mathrm{H}_{\mathrm{i}}$ & -435.015 & 3.04 & 2.04 & & 171.4 \\
\hline $\mathrm{H}_{\mathrm{A} 2}, \mathrm{H}_{\mathrm{B} 2}$ & $\mathrm{H}_{\mathrm{O}}, \mathrm{H}_{\mathrm{i}}$ & -435.000 & 2.91 & 2.04 & & 173.6 \\
\hline $\mathrm{H}_{\mathrm{A} 2}, \mathrm{H}_{\mathrm{D} 4}$ & $\mathrm{H}_{0}, \mathrm{H}_{\mathrm{i}}$ & -434.961 & 2.97 & 2.03 & & 169.5 \\
\hline $\mathrm{H}_{\mathrm{A} 2}, \mathrm{H}_{\mathrm{G} 4}$ & $\mathrm{H}_{0}, \mathrm{H}_{\mathrm{i}}$ & -434.959 & 2.91 & 2.04 & & 174.0 \\
\hline $\mathrm{H}_{\mathrm{A} 2}, \mathrm{H}_{\mathrm{L} 2}$ & $\mathrm{H}_{\mathrm{O}}, \mathrm{H}_{\mathrm{i}}$ & -434.856 & 2.90 & 1.96 & & 173.0 \\
\hline $\mathrm{H}_{\mathrm{A} 2}, \mathrm{H}_{\mathrm{N} 2}$ & $\mathrm{H}_{0}, \mathrm{H}_{\mathrm{i}}$ & -434.839 & 2.89 & 1.98 & & 173.2 \\
\hline $\mathrm{H}_{\mathrm{A} 2}, \mathrm{H}_{\mathrm{C} 2}$ & $\mathrm{H}_{\mathrm{O}}, \mathrm{H}_{\mathrm{i}}$ & -434.797 & 2.84 & 1.97 & & 175.8 \\
\hline Defect sites & Final H positions & Total energy (eV) & $d(O H \cdots O) 1(\AA)$ & $d(O H \cdots O) 2(\AA)$ & $\begin{array}{c}\text { Ti-O-H } \\
\text { angle } 1\end{array}$ & $\begin{array}{c}\text { Ti-O-H } \\
\text { angle } 2\end{array}$ \\
\hline $\mathrm{H}_{\mathrm{D} 3}, \mathrm{H}_{\mathrm{M} 2}$ & $\mathrm{H}_{\mathrm{i}}, \mathrm{H}_{\mathrm{i}}$ & -433.671 & 2.82 & 2.83 & 176.1 & 174.8 \\
\hline $\mathrm{H}_{\mathrm{K} 2}, \mathrm{H}_{\mathrm{G} 3}$ & $\mathrm{H}_{\mathrm{i}}, \mathrm{H}_{\mathrm{i}}$ & -433.588 & 2.91 & 2.94 & 173.1 & 171.6 \\
\hline $\mathrm{H}_{\mathrm{D} 3}, \mathrm{H}_{\mathrm{K} 2}$ & $\mathrm{H}_{\mathrm{i}}, \mathrm{H}_{\mathrm{i}}$ & -433.579 & 2.87 & 2.99 & 175.3 & 172.6 \\
\hline $\mathrm{H}_{\mathrm{D} 3}, \mathrm{H}_{\mathrm{G} 3}$ & $\mathrm{H}_{\mathrm{i}}, \mathrm{H}_{\mathrm{i}}$ & -433.491 & 2.61 & 2.75 & 170.7 & 173.0 \\
\hline Defect sites & Final H positions & Total energy (eV) & $d(O H \cdots O)(\AA ̊)$ & Avg. Ti-H (Å) & & Ti-O-H angle \\
\hline $\mathrm{H}_{\mathrm{K} 2}, \mathrm{H}_{\mathrm{M} 2}$ & $\mathrm{H}_{\mathrm{i}}, \mathrm{H}_{\mathrm{alt}}$ & -432.258 & 3.03 & 1.81 & & 171.7 \\
\hline
\end{tabular}



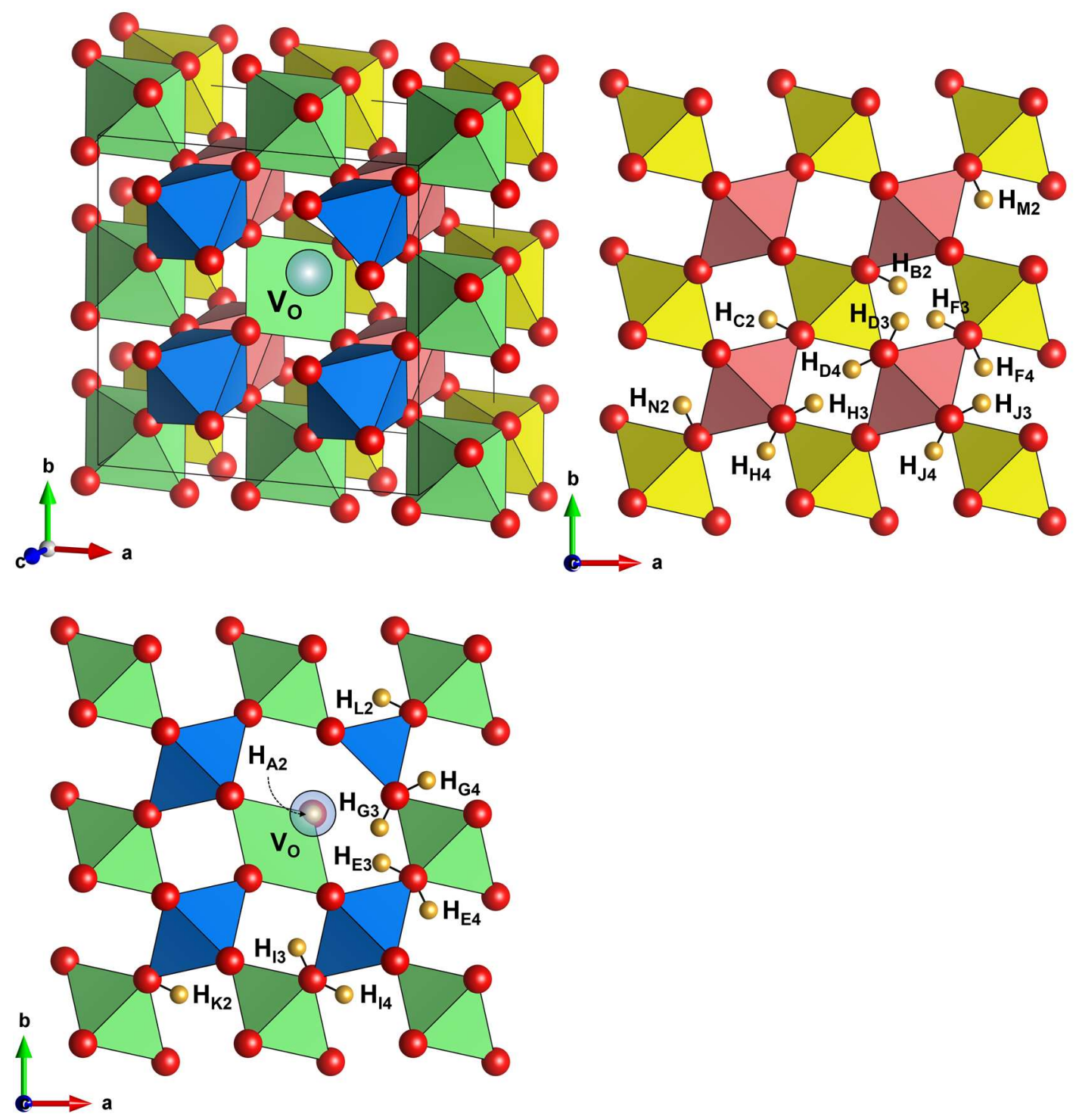

Figure S1. Comprehensive summary of the $\mathrm{O}$ vacancy structure and $\mathrm{H}$ positions from fully relaxed structures with one $\mathrm{O}$ vacancy and one added $\mathrm{H}$. Octahedral Ti sites are color coded by layer in the c-direction. $\mathrm{O}$ atoms are represented by red spheres, $\mathrm{H}$ atoms by bronze spheres, and the $\mathrm{O}$ vacancy (VO) by a transparent blue sphere. All OH-bonds are in a channel-centered orientation. Upon structural relaxation, $\mathrm{H}$ starting in the $\mathrm{A} 2$ position moves to the $\mathrm{O}$ vacancy, rather than forming an $\mathrm{OH}$ bond. All 21 final positions for $\mathrm{H}$ are presented. There are four layers ordered in the c direction: gold, red, green, and blue in sequence. The $\mathrm{O}$ vacancy is in the blue layer. 

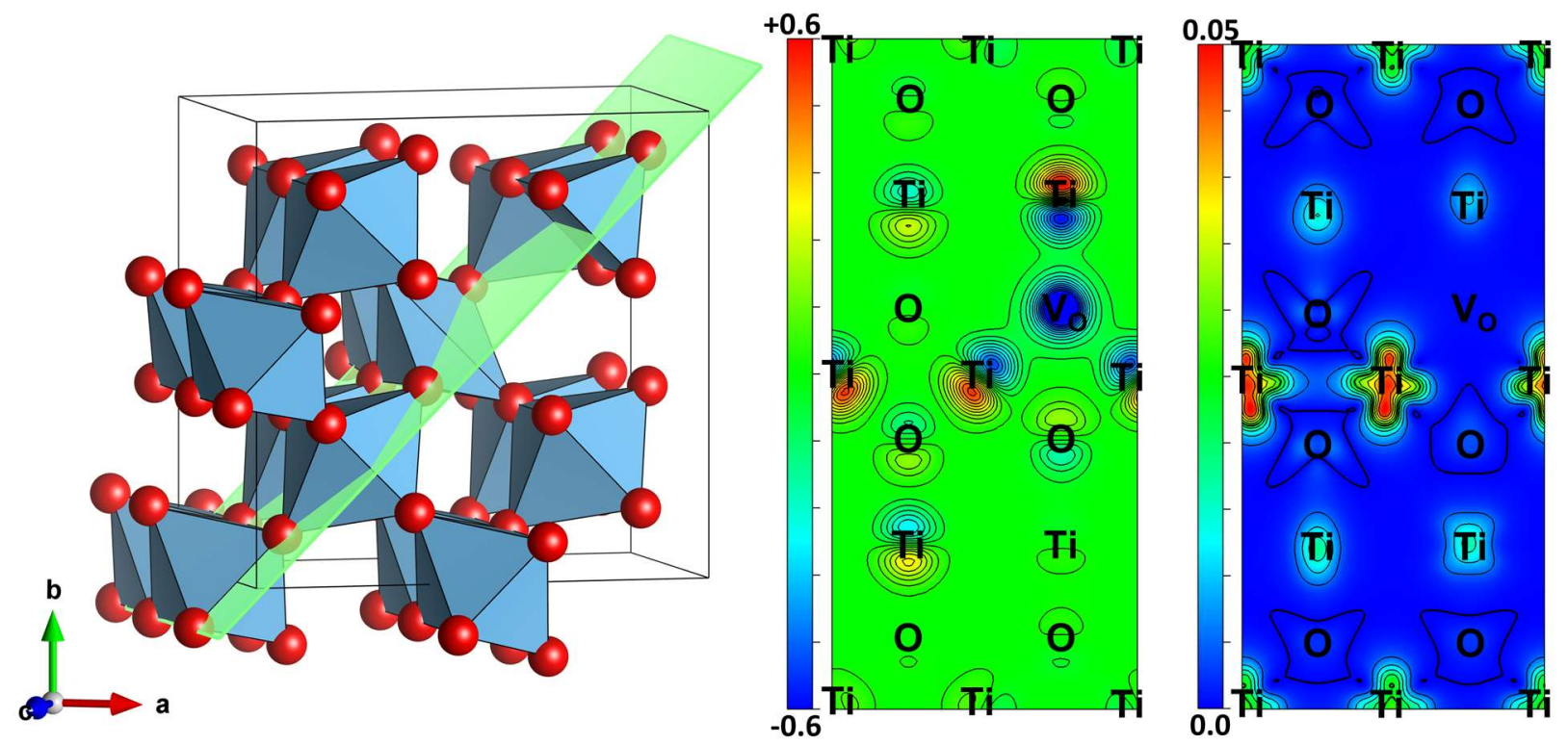

Figure S2. Charge and spin densities for the $\mathrm{O}$ vacancy system with no added H. Left: the (-110) plane, over which the charge and spin densities are plotted, is highlighted in green. Center: The charge density difference between the $\mathrm{O}$ vacancy structure and a perfect rutile crystal. A significant loss of charge is attributed to the $\mathrm{O}$ vacancy. Right: The absolute value spin density for the $\mathrm{O}$ vacancy structure. Despite similar changes in charge between the three Ti atoms surrounding the $\mathrm{O}$ vacancy, the unpaired spin is mostly limited to the two atoms adjacent in the c direction. The shape of the spin density surrounding these $\mathrm{Ti}$ atoms suggests occupation of the dxy orbital. Additionally, some unpaired spin is predicted to occupy Ti atoms further away from the $\mathrm{O}$ vacancy, also adjacent in the $\mathrm{c}$ direction. 

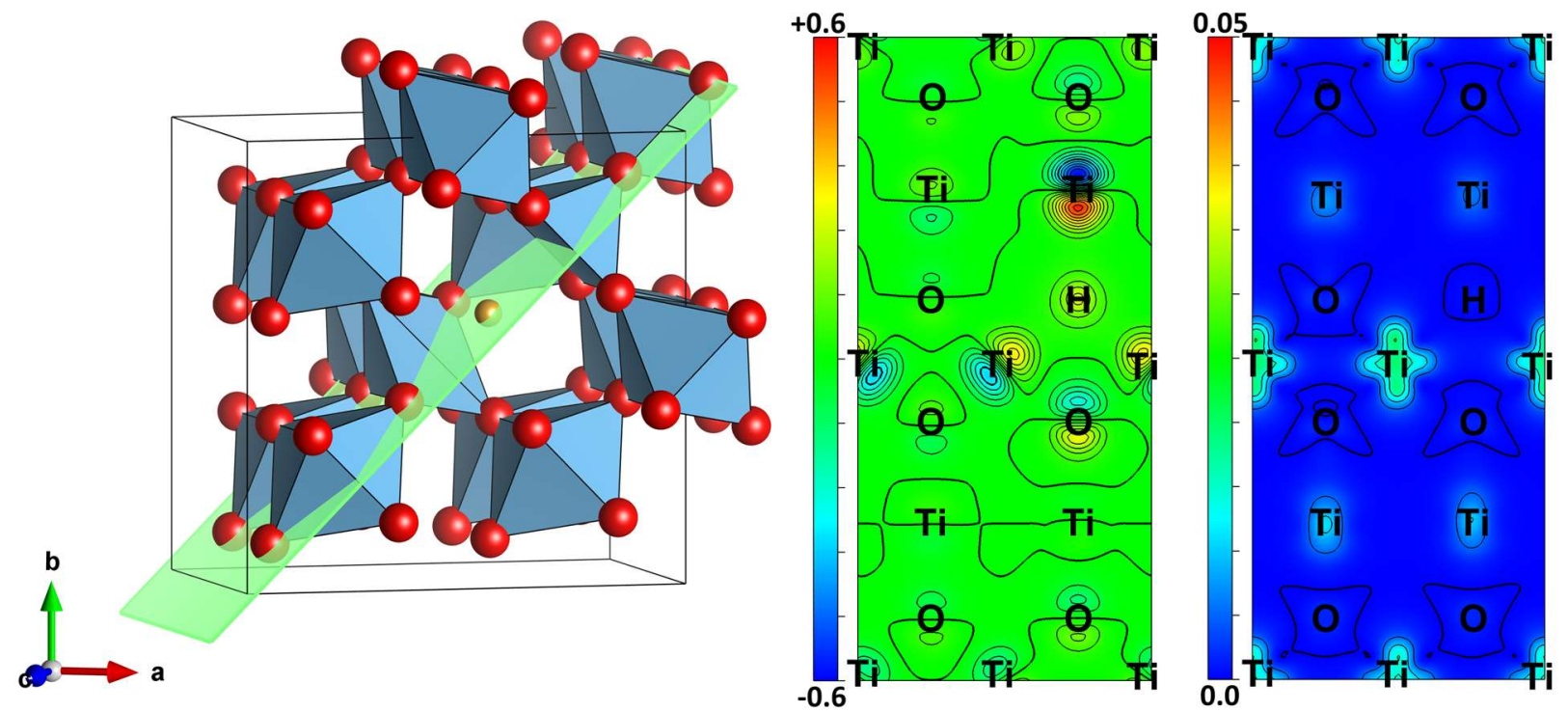

Figure S3. Charge and spin densities for the $\mathrm{H}_{\mathrm{O}}$ defect for the case of one $\mathrm{H}$ added to the $\mathrm{O}$ vacancy structure. Left: the (-110) plane, over which the charge and spin densities are plotted, is highlighted in green. Center: The charge density difference between the $\mathrm{H}_{\mathrm{O}}$ and $\mathrm{O}$ vacancy structure. As expected, there is an increase in charge associated with the inclusion of $\mathrm{H}$. Of the three $\mathrm{Ti}$ atoms surrounding $\mathrm{H}_{\mathrm{O}}$, the one furthest away experiences the greatest net increase in charge, while the two closer Ti atoms experience a relatively modest charge increase. Right: The absolute value spin density for the Ho structure. Similar to the $\mathrm{O}$ vacancy structure, most of the unpaired spin is on the two Ti atoms adjacent in the c direction, while virtually none is associated with the third $\mathrm{H}$-adjacent $\mathrm{Ti}$ atom. This shows the bonding between $\mathrm{H}_{\mathrm{O}}$ and the two adjacent $\mathrm{Ti}$ atoms in the c-direction. 

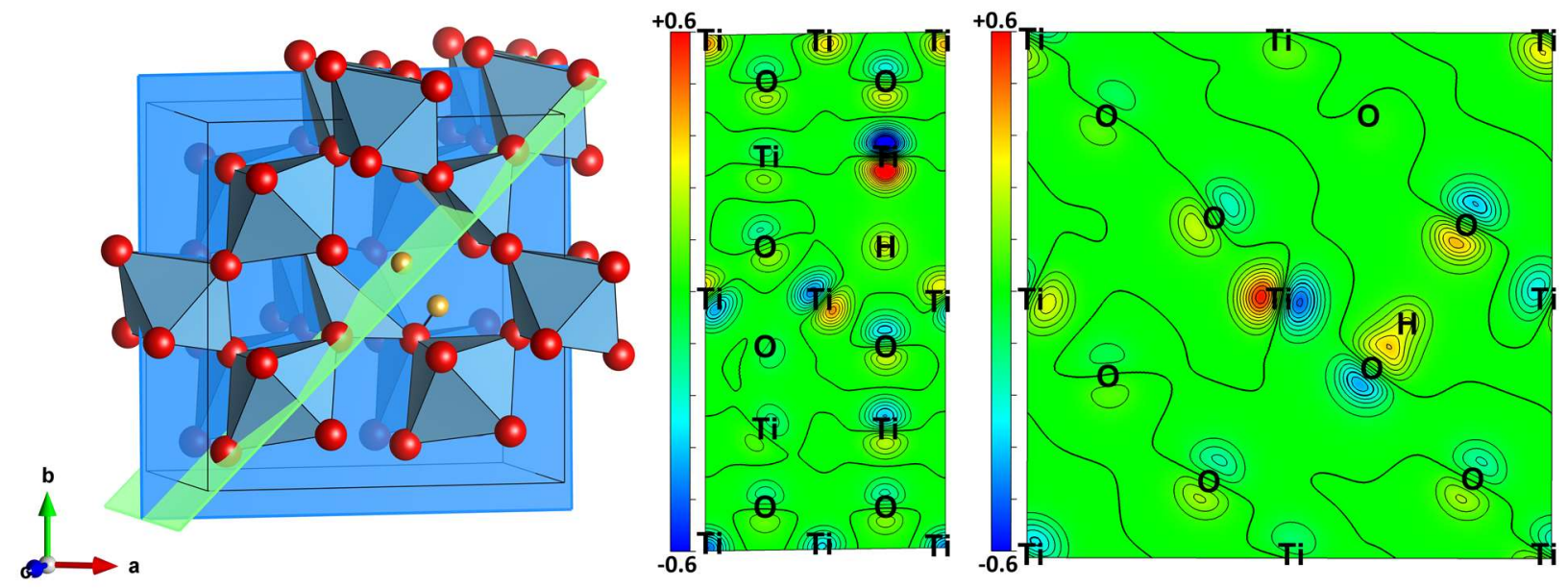

Figure S4. Two $\mathrm{H}$ added to $\mathrm{O}$ vacancy structure. Charge densities for the $\mathrm{H}_{\mathrm{O}}$ defect and $\mathrm{OH}$ in the $2 \mathrm{H}$ system with the $\mathrm{OH}$ bond at the D3 site. Spin density plots are not presented, as virtually no unpaired spin was predicted in these systems. Left: The (-110) and plane (green) and (002) plane (blue), over which the charge density differences have been plotted. Center: The charge density difference in the plane of $\mathrm{H}_{\mathrm{O}}$ and its surrounding $\mathrm{Ti}$ atoms. The charge distribution is largely similar to the single $\mathrm{H}_{\mathrm{O}}$ case. Right: The absolute value spin density is plotted to highlight the charge densities associated with the $\mathrm{OH}$ bond. A continuous positive charge volume exists between $\mathrm{H}$ and its bonded $\mathrm{O}$, revealing the covalent character of the $\mathrm{OH}$ bond. This is in stark contrast with $\mathrm{H}_{\mathrm{O}}$ in the same structure. 
Table S3. Results of Bader charge analyses for the $\mathrm{H}_{\mathrm{i}}$ positioned hydrogen atom in the $2 \mathrm{H}$ defects. Both the charge values and Bader volumes are significantly lower than for $\mathrm{H}_{\mathrm{O}}$, consistent with the formation of $\mathrm{OH}$.

\begin{tabular}{|c|c|c|}
\hline Defect Sites & $\mathrm{H}_{\mathrm{i}}$ Charge & $\mathrm{H}_{\mathrm{i}}$ Volume $\left(\AA^{3}\right)$ \\
\hline $\mathrm{H}_{\mathrm{A} 2}, \mathrm{H}_{\mathrm{M} 2}$ & 0.356 & 1.345 \\
\hline $\mathrm{H}_{\mathrm{A} 2}, \mathrm{H}_{\mathrm{E} 4}$ & 0.375 & 1.359 \\
\hline $\mathrm{H}_{\mathrm{A} 2}, \mathrm{H}_{\mathrm{K} 2}$ & 0.369 & 1.375 \\
\hline $\mathrm{H}_{\mathrm{A} 2}, \mathrm{H}_{\mathrm{G} 3}$ & 0.364 & 1.310 \\
\hline $\mathrm{H}_{\mathrm{A} 2}, \mathrm{H}_{\mathrm{D} 3}$ & 0.366 & 1.288 \\
\hline $\mathrm{H}_{\mathrm{A} 2}, \mathrm{H}_{\mathrm{F} 3}$ & 0.354 & 1.309 \\
\hline $\mathrm{H}_{\mathrm{A} 2}, \mathrm{H}_{13}$ & 0.372 & 1.347 \\
\hline $\mathrm{H}_{\mathrm{A} 2}, \mathrm{H}_{\mathrm{J}}$ & 0.371 & 1.342 \\
\hline $\mathrm{H}_{\mathrm{A} 2}, \mathrm{H}_{\mathrm{H} 4}$ & 0.380 & 1.378 \\
\hline $\mathrm{H}_{\mathrm{A} 2}, \mathrm{H}_{\mathrm{J} 4}$ & 0.393 & 1.476 \\
\hline $\mathrm{H}_{\mathrm{A} 2}, \mathrm{H}_{\mathrm{B} 2}$ & 0.361 & 1.304 \\
\hline $\mathrm{H}_{\mathrm{A} 2}, \mathrm{H}_{\mathrm{D} 4}$ & 0.390 & 1.440 \\
\hline $\mathrm{H}_{\mathrm{A} 2}, \mathrm{H}_{\mathrm{G} 4}$ & 0.372 & 1.353 \\
\hline $\mathrm{H}_{\mathrm{A} 2}, \mathrm{H}_{\mathrm{L} 2}$ & 0.364 & 1.327 \\
\hline $\mathrm{H}_{\mathrm{A} 2}, \mathrm{H}_{\mathrm{N} 2}$ & 0.370 & 1.327 \\
\hline $\mathrm{H}_{\mathrm{A} 2}, \mathrm{H}_{\mathrm{C} 2}$ & 0.360 & 1.281 \\
\hline AVERGE & 0.370 & 1.348 \\
\hline
\end{tabular}


Table S4. Results of Bader charge analyses for the $\mathrm{H}_{\mathrm{O}}$ positioned hydrogen atom in the $2 \mathrm{H}$ defects and $\mathrm{H}_{\mathrm{A} 2}$. Both the charge values and Bader volumes are significantly higher than for $\mathrm{H}_{\mathrm{i}}$, consistent with anionic hydrogen.

\begin{tabular}{|c|c|c|}
\hline DEFECT & Ho CHARGE & $\mathrm{H}_{\mathrm{O}}$ VOLUME $\left(\AA^{3}\right)$ \\
\hline $\mathrm{H}_{\mathrm{A} 2}, \mathrm{H}_{\mathrm{M} 2}$ & 1.571 & 8.157 \\
\hline $\mathrm{H}_{\mathrm{A} 2}, \mathrm{H}_{\mathrm{E} 4}$ & 1.578 & 8.126 \\
\hline $\mathrm{H}_{\mathrm{A} 2}, \mathrm{H}_{\mathrm{K} 2}$ & 1.572 & 8.061 \\
\hline $\mathrm{H}_{\mathrm{A} 2}, \mathrm{H}_{\mathrm{G} 3}$ & 1.569 & 7.868 \\
\hline $\mathrm{H}_{\mathrm{A} 2}, \mathrm{H}_{\mathrm{D} 3}$ & 1.563 & 7.891 \\
\hline $\mathrm{H}_{\mathrm{A} 2}, \mathrm{H}_{\mathrm{F} 3}$ & 1.579 & 8.203 \\
\hline $\mathrm{H}_{\mathrm{A} 2}, \mathrm{H}_{13}$ & 1.575 & 8.174 \\
\hline $\mathrm{H}_{\mathrm{A} 2}, \mathrm{H}_{\mathrm{J3}}$ & 1.570 & 8.126 \\
\hline $\mathrm{H}_{\mathrm{A} 2}, \mathrm{H}_{\mathrm{H} 4}$ & 1.572 & 8.131 \\
\hline $\mathrm{H}_{\mathrm{A} 2}, \mathrm{H}_{\mathrm{J} 4}$ & 1.572 & 8.179 \\
\hline $\mathrm{H}_{\mathrm{A} 2}, \mathrm{H}_{\mathrm{B} 2}$ & 1.567 & 8.235 \\
\hline $\mathrm{H}_{\mathrm{A} 2}, \mathrm{H}_{\mathrm{D} 4}$ & 1.574 & 8.247 \\
\hline $\mathrm{H}_{\mathrm{A} 2}, \mathrm{H}_{\mathrm{G} 4}$ & 1.580 & 8.403 \\
\hline $\mathrm{H}_{\mathrm{A} 2}, \mathrm{H}_{\mathrm{L} 2}$ & 1.573 & 7.595 \\
\hline $\mathrm{H}_{\mathrm{A} 2}, \mathrm{H}_{\mathrm{N} 2}$ & 1.578 & 7.800 \\
\hline $\mathrm{H}_{\mathrm{A} 2}, \mathrm{H}_{\mathrm{C} 2}$ & 1.573 & 7.746 \\
\hline $\mathrm{H}_{\mathrm{A} 2}$ & 1.567 & 8.174 \\
\hline AVERAGE & 1.573 & 8.066 \\
\hline
\end{tabular}




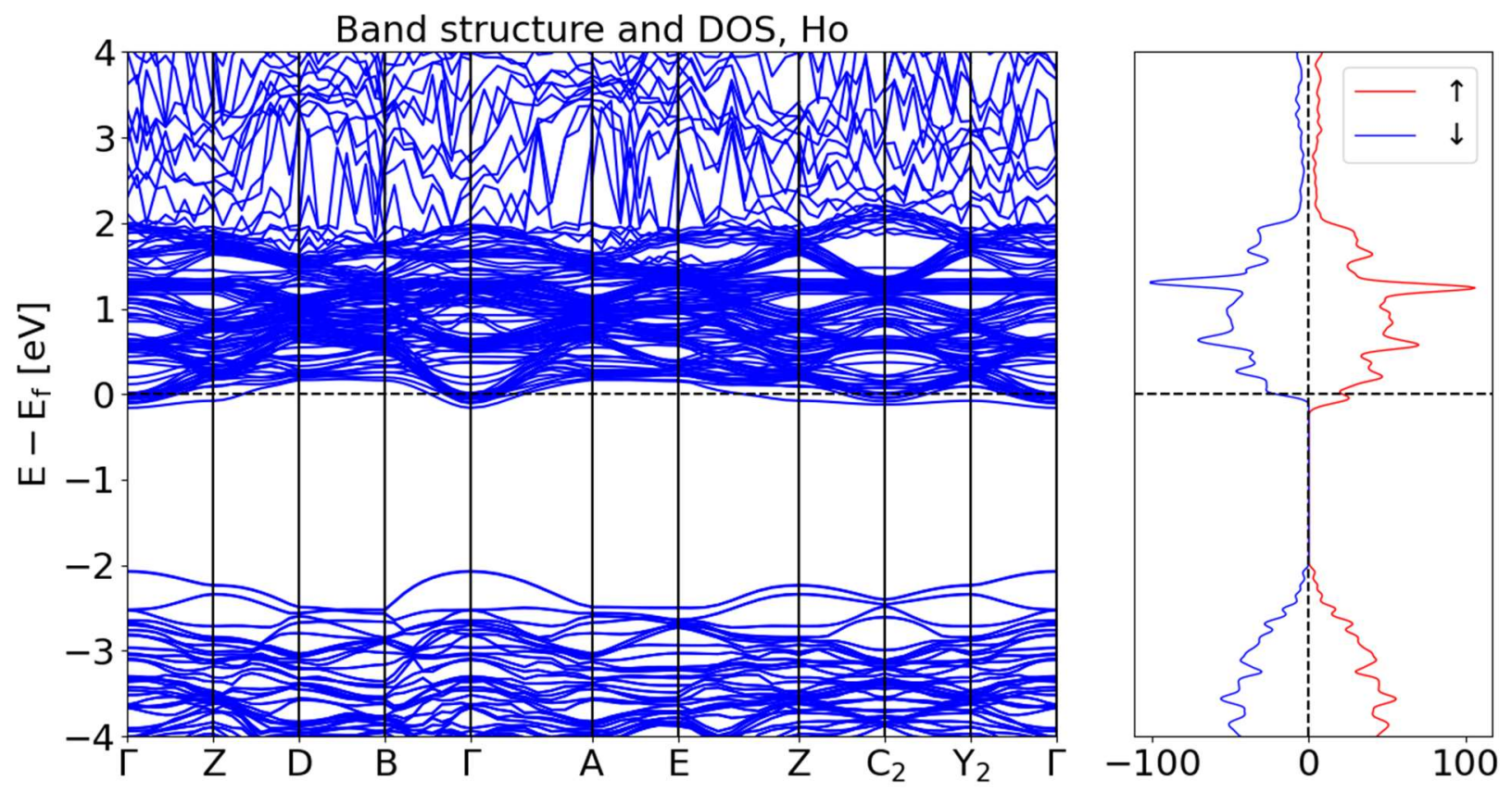

Figure S5. Band structure (left) and density of states (right) for the single hydrogen, $\mathrm{H}_{\mathrm{O}}$ defect $\left(\mathrm{H}_{\mathrm{A} 2}\right.$ case). Note the states and unpaired spin present just below the Fermi energy. This is attributed to the excess electrons resulting from $\mathrm{V}_{\mathrm{O}}$ which have been delocalized across $\mathrm{Ti}$ atoms throughout the structure. The largest portion of the unpaired spin and excess charge is confined to the two $\mathrm{Ti}$ atoms bonded to $\mathrm{H}_{\mathrm{O}}$. 

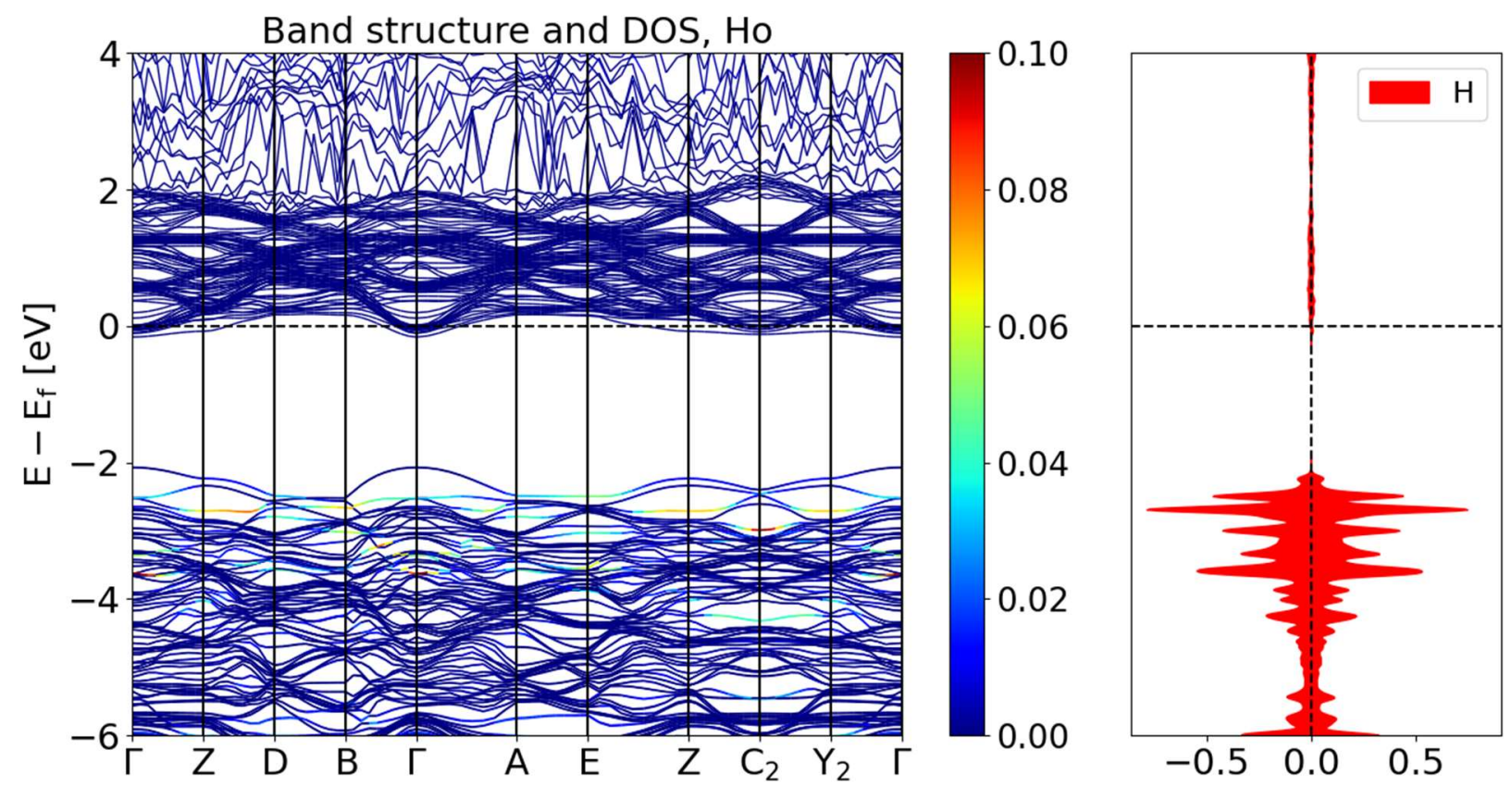

Figure S6. Band structure (left) and density of states (right) for the single hydrogen, $\mathrm{H}_{\mathrm{O}}$ defect $\left(\mathrm{H}_{\mathrm{A} 2}\right.$ case). Only the states attributed to $\mathrm{H}$ are plotted on the right, and the corresponding bands are highlighted on the left, with warmer colors indicating higher levels of occupation. The $\mathrm{Ti}_{\mathrm{dxy}}-\mathrm{H}_{\mathrm{s}}-\mathrm{Ti}_{\mathrm{dxy}}$ to $\mathrm{Ti}_{\mathrm{dxy}}-\mathrm{Ti}_{\mathrm{dxy}}$ transition is measured from the highest $\mathrm{H}$ band to the Ti bands present just below the Fermi energy. 


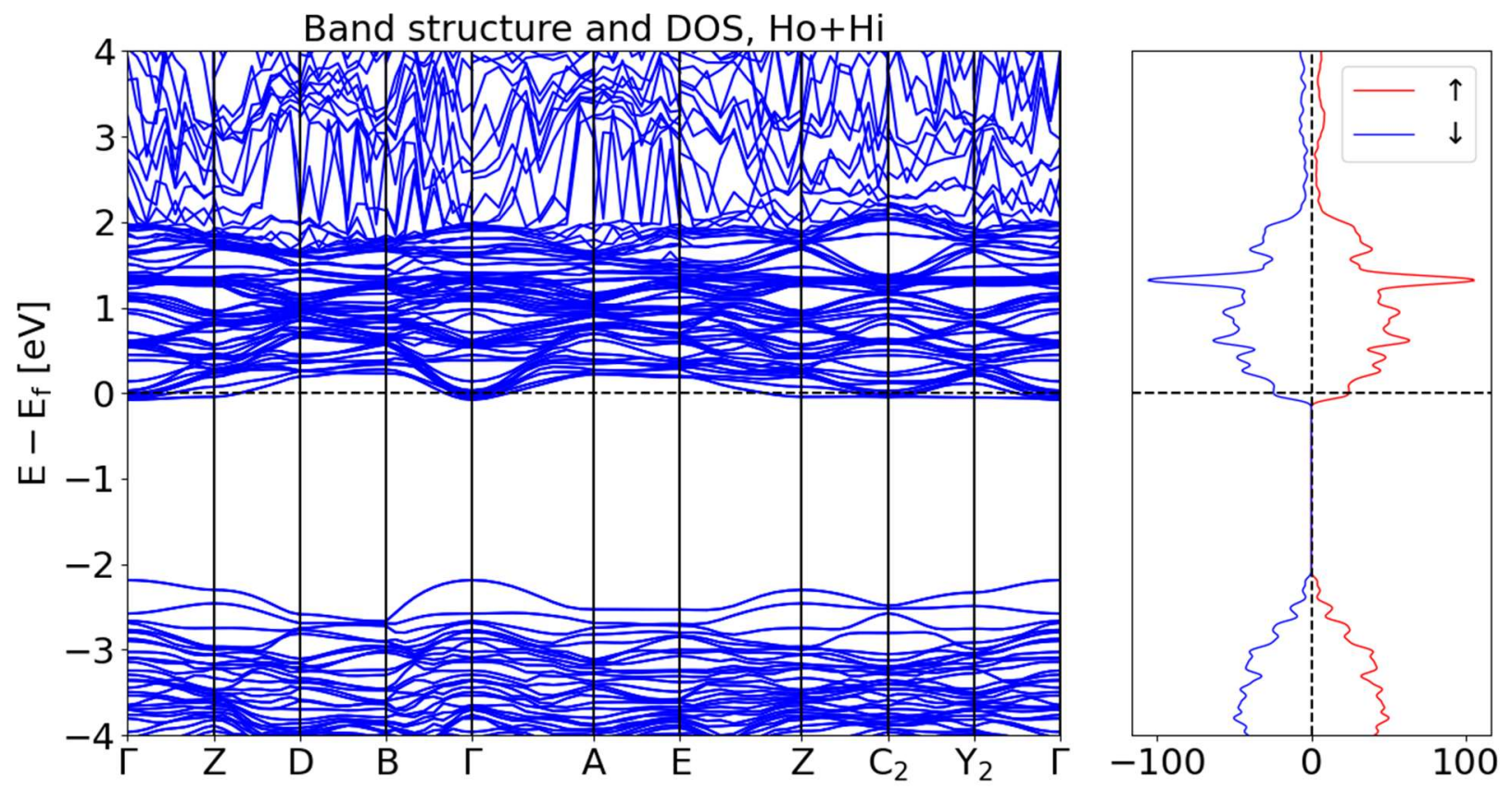

Figure S7. Band structure (left) and density of states (right) for the two hydrogen, $\mathrm{H}_{\mathrm{O}}+\mathrm{H}_{\mathrm{i}}$ defect system $\left(\mathrm{H}_{\mathrm{A} 2}, \mathrm{H}_{\mathrm{M} 2}\right.$ case $)$. Note the states present just below the Fermi energy, similar to the single hydrogen case. However, in contrast to the single hydrogen case, this system has no unpaired spins. The largest portion of the excess charge resulting from $\mathrm{V}_{\mathrm{O}}$ is confined to the two Ti atoms bonded to $\mathrm{H}_{\mathrm{O}}$, with the remained being delocalized across other Ti pairs. 

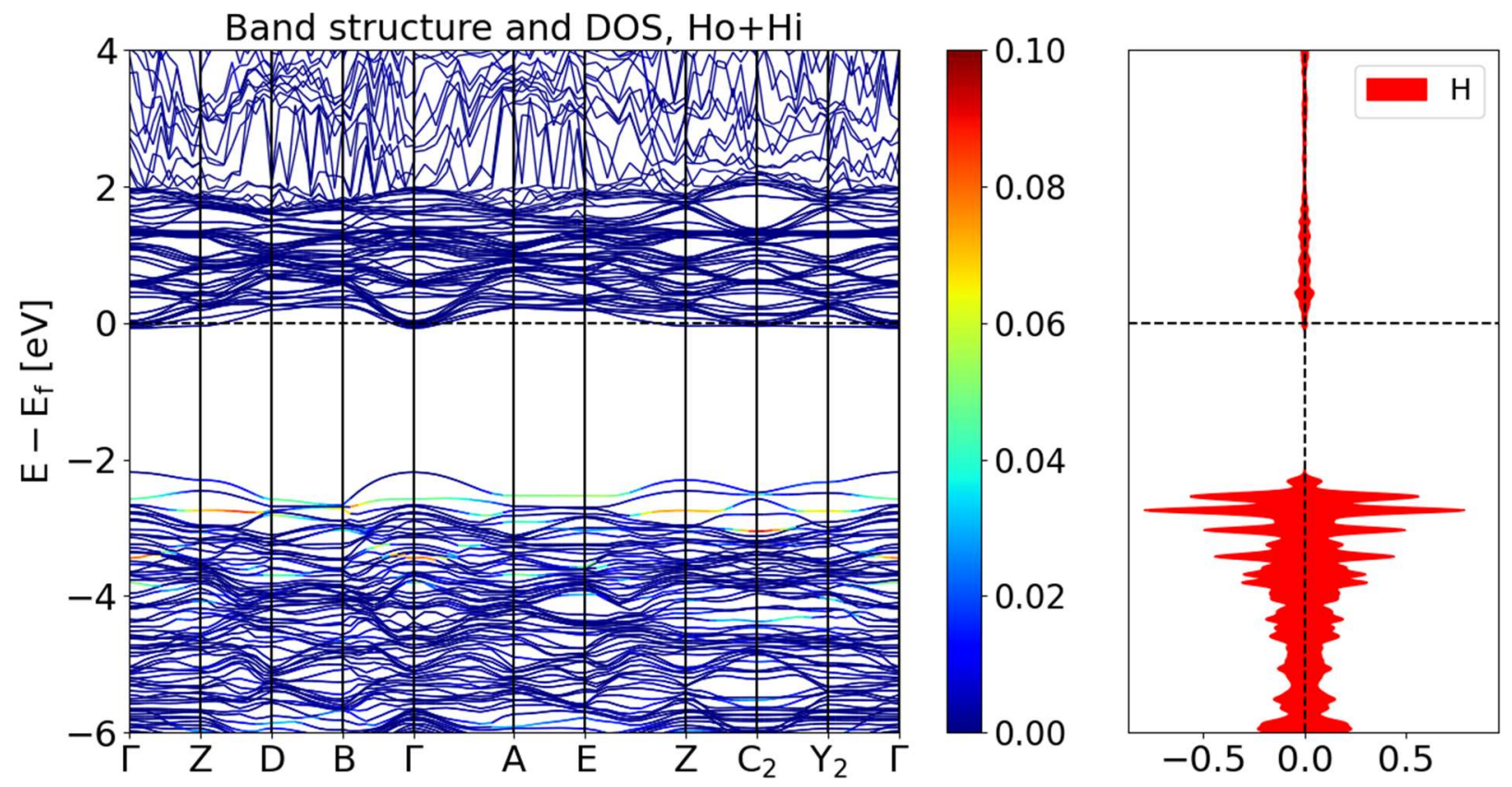

Figure S8. Band structure (left) and density of states (right) for the two hydrogen, $\mathrm{H}_{\mathrm{O}}+\mathrm{H}_{\mathrm{i}}$ defect system $\left(\mathrm{H}_{\mathrm{A} 2}, \mathrm{H}_{\mathrm{M} 2}\right.$ case). Only the states attributed to $\mathrm{H}$ are plotted on the right, and the corresponding bands are highlighted on the left, with warmer colors indicating higher levels of occupation. The $\mathrm{Ti}_{\mathrm{dxy}}-\mathrm{H}_{\mathrm{s}}-\mathrm{Ti}_{\mathrm{dxy}}$ to $\mathrm{Ti}_{\mathrm{dxy}}-\mathrm{Ti}_{\mathrm{dxy}}$ transition is again measured from the highest $\mathrm{H}$ band to the Ti bands present just below the Fermi energy, similar to the single hydrogen case. 
Table S5. All calculated $\mathrm{H}$-associated vibrational modes are presented above. Emphasis was placed on calculating modes for either structures with unusual geometries (i.e. short or long bond lengths) or the lowest energy structures (i.e. those with Boltzmann factors of 0.05 or more at 25 C).

\begin{tabular}{|c|c|c|c|}
\hline Defect site & OH mode $\left(\mathrm{cm}^{-1}\right)$ & Ho mode $\left(\mathrm{cm}^{-1}\right)$ & $25^{\circ} \mathrm{C}$ Boltzmann Factor \\
\hline $\mathrm{H}_{\mathrm{A} 2}$ & $\mathrm{~N} / \mathrm{A}$ & 1198.1 & 1.00 \\
\hline $\mathrm{H}_{\mathrm{K} 2}$ & 3316.3 & $\mathrm{~N} / \mathrm{A}$ & $1.02 \mathrm{E}-24$ \\
\hline $\mathrm{H}_{\mathrm{D} 3}$ & 3171.7 & $\mathrm{~N} / \mathrm{A}$ & $5.01 E-25$ \\
\hline $\mathrm{H}_{\mathrm{M} 2}$ & 3287.1 & $\mathrm{~N} / \mathrm{A}$ & $4.06 \mathrm{E}-25$ \\
\hline $\mathrm{H}_{\mathrm{E} 4}$ & 3242.5 & $\mathrm{~N} / \mathrm{A}$ & $6.75 E-26$ \\
\hline $\mathrm{H}_{\mathrm{G} 3}$ & 3118.6 & $\mathrm{~N} / \mathrm{A}$ & $2.35 E-26$ \\
\hline $\mathrm{H}_{\mathrm{J4}}$ & 3454.8 & $\mathrm{~N} / \mathrm{A}$ & $2.09 \mathrm{E}-27$ \\
\hline $\mathrm{H}_{\mathrm{B} 2}$ & 3330.9 & $\mathrm{~N} / \mathrm{A}$ & $1.78 \mathrm{E}-27$ \\
\hline $\mathrm{H}_{13}$ & 3339.5 & $\mathrm{~N} / \mathrm{A}$ & $1.40 \mathrm{E}-27$ \\
\hline $\mathrm{H}_{\mathrm{H} 3}$ & 3383.5 & $\mathrm{~N} / \mathrm{A}$ & $1.04 \mathrm{E}-27$ \\
\hline Defect sites & OH mode $\left(\mathrm{cm}^{-1}\right)$ & Ho mode $\left(\mathrm{cm}^{-1}\right)$ & $25^{\circ} \mathrm{C}$ Boltzmann Factor \\
\hline $\mathrm{H}_{\mathrm{A} 2}, \mathrm{H}_{\mathrm{M} 2}$ & 3270.3 & 1201.5 & 1.000 \\
\hline $\mathrm{H}_{\mathrm{A} 2}, \mathrm{H}_{\mathrm{E} 4}$ & 3251.4 & 1239.7 & 0.715 \\
\hline $\mathrm{H}_{\mathrm{A} 2}, \mathrm{H}_{\mathrm{K} 2}$ & 3298.8 & 1243.1 & 0.700 \\
\hline $\mathrm{H}_{\mathrm{A} 2}, \mathrm{H}_{\mathrm{G} 3}$ & 3151.3 & 1212.5 & 0.465 \\
\hline $\mathrm{H}_{\mathrm{A} 2}, \mathrm{H}_{\mathrm{D} 3}$ & 3130.8 & 1211.3 & 0.408 \\
\hline $\mathrm{H}_{\mathrm{A} 2}, \mathrm{H}_{\mathrm{F} 3}$ & 3295.7 & 1220.0 & 0.131 \\
\hline $\mathrm{H}_{\mathrm{A} 2}, \mathrm{H}_{13}$ & 3238.6 & 1210.2 & 0.112 \\
\hline $\mathrm{H}_{\mathrm{A} 2}, \mathrm{H}_{\mathrm{J} 3}$ & 3259.3 & 1197.9 & 0.065 \\
\hline $\mathrm{H}_{\mathrm{A} 2}, \mathrm{H}_{\mathrm{H} 4}$ & 3267.7 & 1196.0 & 0.051 \\
\hline $\mathrm{H}_{\mathrm{A} 2}, \mathrm{H}_{\mathrm{J} 4}$ & 3364.9 & 1217.9 & 0.047 \\
\hline $\mathrm{H}_{\mathrm{A} 2}, \mathrm{H}_{\mathrm{B} 2}$ & 3255.4 & 1216.7 & 0.027 \\
\hline $\mathrm{H}_{\mathrm{A} 2}, \mathrm{H}_{\mathrm{D} 4}$ & 3279.4 & 1224.6 & $5.81 E-03$ \\
\hline $\mathrm{H}_{\mathrm{A} 2}, \mathrm{H}_{\mathrm{G} 4}$ & 3231.5 & 1214.7 & 5.47E-03 \\
\hline $\mathrm{H}_{\mathrm{A} 2}, \mathrm{H}_{\mathrm{L} 2}$ & 3194.7 & 1503.0 & $9.74 \mathrm{E}-05$ \\
\hline $\mathrm{H}_{\mathrm{A} 2}, \mathrm{H}_{\mathrm{N} 2}$ & 3188.8 & 1328.2 & 5.03E-05 \\
\hline
\end{tabular}




\begin{tabular}{|c|c|c|c|}
\hline $\mathrm{H}_{\mathrm{A} 2}, \mathrm{H}_{\mathrm{C} 2}$ & 3088.3 & 1301.7 & $1.00 \mathrm{E}-05$ \\
\hline Defect sites & OH mode $1\left(\mathrm{~cm}^{-1}\right)$ & $\mathrm{OH}$ mode $2\left(\mathrm{~cm}^{-1}\right)$ & $25^{\circ} \mathrm{C}$ Boltzmann Factor \\
\hline $\mathrm{H}_{\mathrm{D} 3}, \mathrm{H}_{\mathrm{G} 3}$ & 2798.5 & 3003.0 & $8.42 \mathrm{E}-28$ \\
\hline Defect sites & \multicolumn{2}{|c|}{$\mathrm{OH}$ mode $\left(\mathrm{cm}^{-1}\right)$} & $25^{\circ} \mathrm{C}$ Boltzmann Factor \\
\hline $\mathrm{H}_{\mathrm{K} 2}, \mathrm{H}_{\mathrm{M} 2}$ & \multicolumn{2}{|l|}{3370.2} & $1.21 \mathrm{E}-48$ \\
\hline
\end{tabular}




\section{Additional commentary on the relation between $\mathrm{d}(\mathrm{OH} \cdots \mathrm{O})$ and $\mathrm{OH}$ frequencies}

Figure S9 compares our predicted $\mathrm{OH}$ stretching frequencies and hydrogen bonding distances to the relation derived by Libowitzky et al. (1999). Although the trends are generally similar (longer bonding distances correspond to higher wavenumber vibrations), the behavior of our calculated modes deviates somewhat from the experimental observations. These systemic errors in the $\mathrm{OH}$ modes may arise from the PBE level of DFT. Although the energies of the vibrational modes we report here are likely close to their true values (within $\sim 100 \mathrm{~cm}^{-1}$ ), we suggest that these calculations may lack the accuracy required to confidently identify defects contributing to specific vibrational modes.

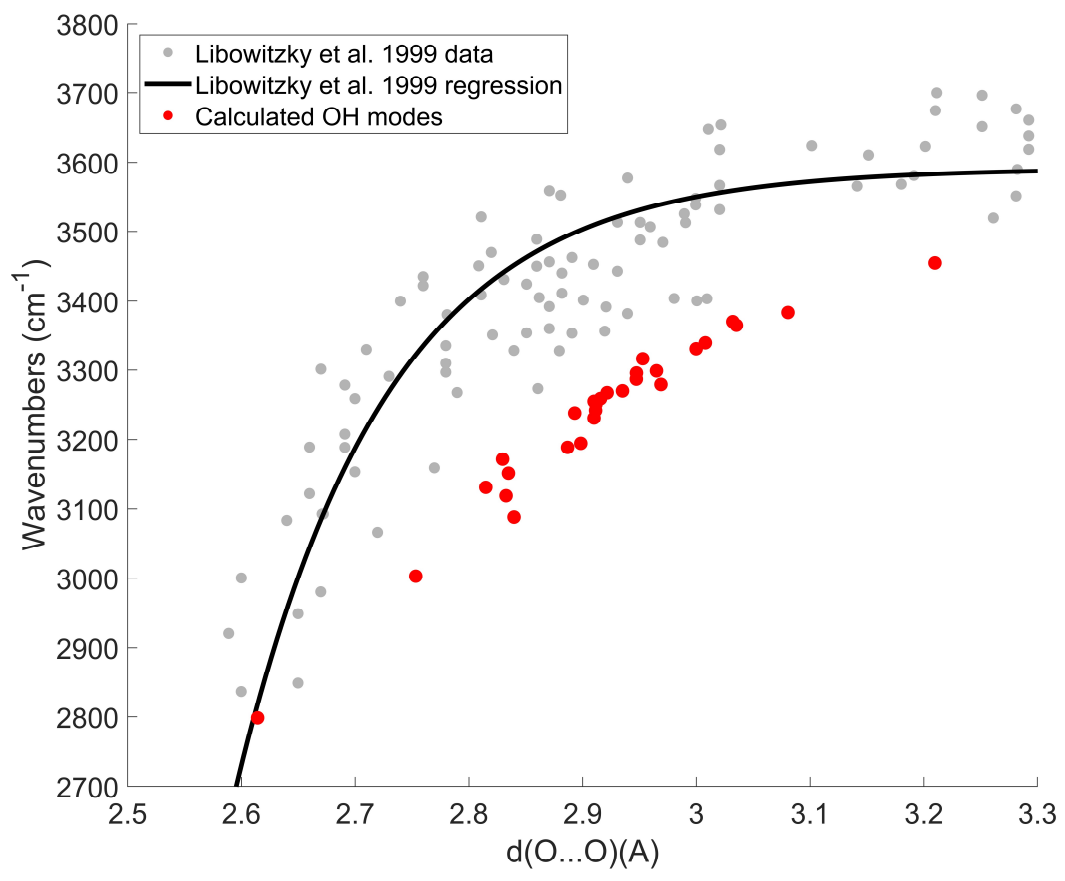

Figure S9. Plot of hydrogen bonding distance $(\mathrm{d}(\mathrm{OH} \cdots \mathrm{O}))$ versus DFPT-calculated OH stretching frequencies for both $1 \mathrm{H}$ and $2 \mathrm{H}$ defects (red) compared to the survey data and regression curve from Libowitzky et al., 1999 (gray and black, respectively). Although the two datasets show similar trends, the DFPT calculated modes generally lie outside the experimental data scatter, suggesting a possible underestimation of frequency for given $\mathrm{d}(\mathrm{OH} \cdots \mathrm{O})$ values. 


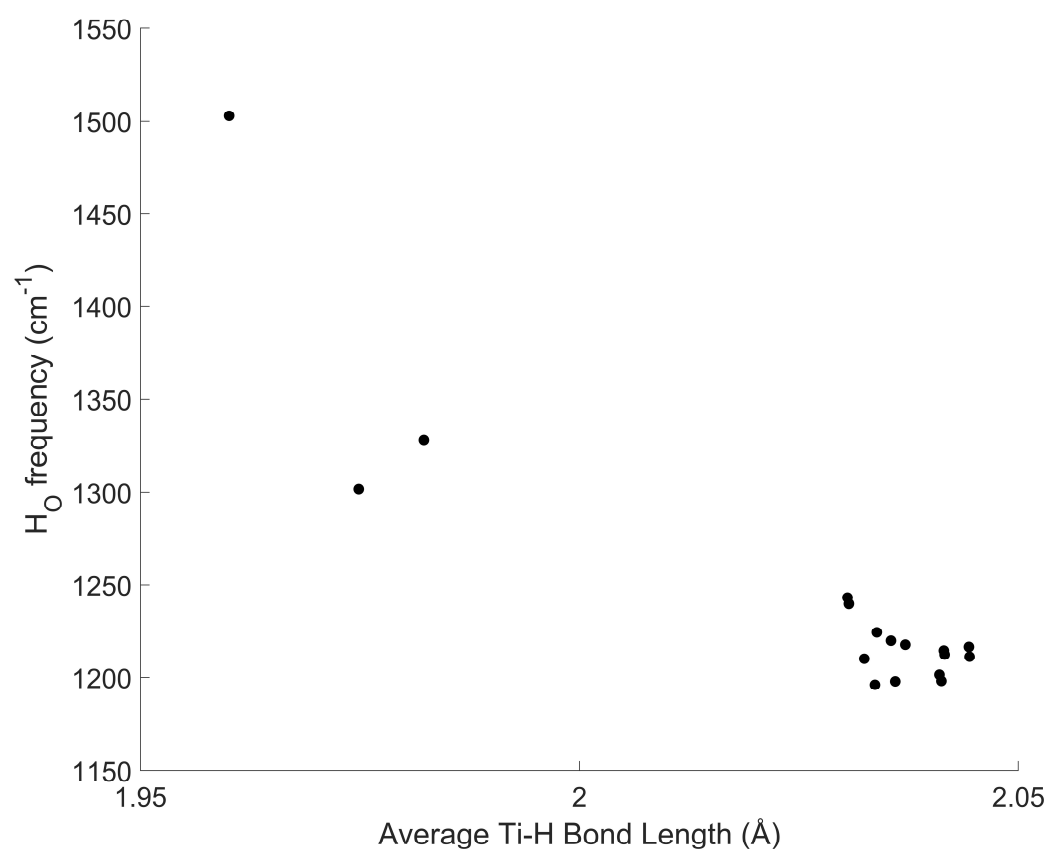

Figure S10. Plot of average Ti-H distance versus DFPT-calculated HO stretching frequencies. Although most of the $\mathrm{HO}$ frequencies are clustered in a narrow range of Ti-H distances, expanding the plot to include unusually short Ti-H lengths reveals the response of $\mathrm{HO}$ frequencies to bonding lengths. The overall relation mimics trends observed in other types of bonds, further supporting the possibility of $\mathrm{H}$ bonded to Ti. 


\section{Details on the calculation of heat of formation energies}

We estimated the heats of formation for the defect structures using the total energies calculated from the minimized defect structures in addition to the total energies corresponding to the minimized structures of a perfect rutile cell (denoted below as $\mathrm{TiO}_{2}$ ), a rutile cell with a single oxygen vacancy (denoted below as $\mathrm{TiO}_{x}$ ), a single $\mathrm{H}_{2}$ molecule, and a single $\mathrm{H}_{2} \mathrm{O}$ molecule. $\mathrm{H}_{2} \mathrm{O}$ and $\mathrm{H}_{2}$ were used in favor of $\mathrm{O}_{2}$ to avoid errors inherent to the PBE description of triplet $\mathrm{O}_{2}$. The heats of formation for each defect type were calculated as follows:

O vacancy:

$$
\Delta H_{f}=\left(E_{T_{i O}}+E_{H_{2} O}\right)-\left(E_{T_{i O}}+E_{H_{2}}\right)
$$

\section{O vacancy, one $\mathrm{H}$ :}

$$
\Delta H_{f}=\left(E_{\mathrm{TiO}_{x} \mathrm{H}}+E_{\mathrm{H}_{2} \mathrm{O}}\right)-\left(E_{\mathrm{TiO}_{2}}+\frac{3}{2} E_{\mathrm{H}_{2}}\right)
$$

\section{O vacancy, two H:}

$$
\Delta H_{f}=\left(E_{\mathrm{TiO}_{x} \mathrm{H}_{2}}+E_{\mathrm{H}_{2} \mathrm{O}}\right)-\left(E_{\mathrm{TiO}_{2}}+2 E_{\mathrm{H}_{2}}\right)
$$

These values were then adjusted for the heat of formation of $\mathrm{O}_{2}$ in $\mathrm{H}_{2} \mathrm{O}$, which we calculated from NIST thermochemistry data of $-2.506 \mathrm{eV}$. The other total energy values used in the calculations above are presented below:

Perfect rutile crystal: $-437.83 \mathrm{eV}$

Rutile crystal with one O vacancy: $-427.61 \mathrm{eV}$

$\mathrm{H}_{2} \mathrm{O}$ gas molecule: $-14.22 \mathrm{eV}$

$\mathrm{H}_{2}$ gas molecule: $-6.77 \mathrm{eV}$ 


\section{Accuracy of PBE-D3 level of DFT}

We have used PBE-D3 for a number of catalysis and electrocatalysis experiments for which we have excellent agreement with experiment. For example:

Oxygen evolution reaction over catalytic single-site $\mathrm{Co}$ in a well-defined brookite $\mathrm{TiO}_{2}$ nanorod surface. C. Liu, J. Qian, Y. Ye, H. Zhou, C.-J. Sun, C. Sheehan, Z. Zhang, G. Wan, Y.-S. Liu, J. Guo, S. Li, H. Shin, S. Hwang, T.B. Gunnoe, W.A. Goddard III and S. Zhang. Nat. Catal. 4 (1):3645 (2021) DOI: 10.1038/s41929-020-00550-5

Reaction mechanism and kinetics for ammonia synthesis on the Fe(111) Surface. J. Qian; Q. An; A. Fortunelli; R.J. Nielsen \& W.A. Goddard III. J. Am. Chem. Soc. 140 (20):6288-6297 (2018) DOI: $10.1021 /$ jacs. $7 b 13409$

Both papers do full kinetics to obtain the TOF. The agreement with experimental rates indicating accuracy better than $0.05 \mathrm{eV}$. 